\title{
Still waiting for health reform
}

Although Prime Minister Paul Martin had hailed the Sept. 16 health agreement as a "deal for a decade," some premiers warn they may place demands on the federal coffers before the 10 years are up, and the architects of the deal consider it a foundation, not a reform package.

Here's a synopsis of the new funding agreement:

\section{The money}

- The agreement allocates $\$ 41$ billion over 10 years in new federal money, provided primarily through the Canada Health Transfer (CHT) payments each province receives.

- Beginning in 2005/06, the base CHT rate will be $\$ 19$ billion a year and will include an "escalator" of $6 \%$ per year, beginning in 2006/07.

- Starting in 2010/11, \$250 million a year will be added to the base CHT to address human resources shortages.

\section{Included in the $\mathbf{\$ 1} 1$ billion}

- \$1 billion in 2004/05 and \$2 billion in 2005/06 to close the so-called Romanow gap. (The money will be paid through the CHT.)

- $\$ 500$ million in 2005/06 to "deepen progress on home care services and catastrophic drug coverage," paid through the CHT.

- $\$ 500$ million for new medical equipment in 2004/05.

- $\$ 4.5$ billion over 6 years, beginning in 2004/05, for the Wait Times Reduction Fund.

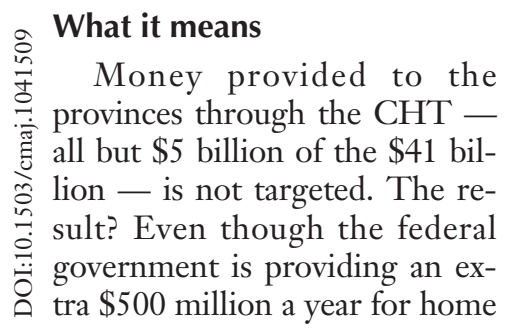

care and catastrophic drug coverage, there is no penalty to the provinces if they don't spend the money in those areas, and no guarantee that they will.

Similarly, the $\$ 250$ million per year for human resources which will be paid out starting 5 years from now - is not targeted through any separate fund or organization, but simply lumped in with a general transfer.

\section{What the agreement doesn't do}

- Address the human resource shortage in any immediate, concentrated or organized fashion.

- Create a pharmacare plan.

- Provide catastrophic drug coverage or a home care plan.

- Reform the health care system

- Address the issue of privatization.

- Discuss the collection of data necessary to enforce the Canada Health Act, or the establishment of enforcement mechanisms.

Neither patients nor physicians are likely to feel any appreciable impact from this agreement for several years, until some of the money begins to flow and is then translated into action, says Michael Rachlis, a health policy analyst and author of Prescription for Excellence: How Innovation is Saving Canada's Health Care System. The biggest drawback to the deal is that most of the money isn't targeted, he says.

"There was no action on the for-profit issue," Rachlis says. "Another big minus is that there are no real plans for an effective health human resource strategy."

Without targeting, less money goes to reform, he says. "Most of the money simply goes to pay people more for what they're already doing. The immediate impact isn't likely to be on patient care, and is likely to be on increases for salaries," he says.
Former Saskatchewan premier Roy Romanow called the "deafening silence" around the public discussion about private health care delivery "disappointing" in the Toronto Star on Sept. 20. Though Romanow is, overall, pleased that the issue of money is no longer reason to delay reform, he recognizes that the critical issue of putting reforms in place remains ahead. $\mathrm{He}$ also calls for stronger consequences when a province does not comply with the Canada Health Act. - Laura Eggertson, CMAJ

\section{The agreement}

Waiting lists

- The premiers committed themselves to achieving "meaningful reductions" in waiting times for cancer and cardiac care, diagnostic imaging, joint replacements and sight restoration by Mar. 31, 2007.

- By Dec. 31, 2005, premiers are to report to their citizens on what those waiting times are, after establishing comparable indicators of access.

- By the same deadline, provincial health ministers are to have agreed on evidence-based benchmarks of waiting times for cardiac and cancer care, diagnostic imaging procedures, joint replacements and sight restoration.

Human resources

- By Dec. 31, 2005, premiers are to make public their plans on how to increase the supply of health care professionals.

- Ottawa is to "accelerate and expand assessment and integration of internationally trained health care graduates."

- Ottawa is to take measures to reduce the financial burden on students in specific health education programs.

- The premiers and the federal government will seek to increase the supply of health care professionals in Aboriginal and in minority francophone and anglophone communities.

Home care

- By 2006, the first ministers are to provide "first-dollar coverage" for home care services, including short-term acute home care (2 weeks) after discharge, such as nursing, personal care and intravenous medications.

- Community mental health home care (2 weeks) for case management and crisis response situations; palliative care.

Primary care

- The agreement calls for the establishment of a best practices network and the accelerated development of eprescribing and e-health records networks.

\section{Pharmacare}

- A ministerial task force on national pharmaceuticals is to report by June 30,2006 , and to establish a common national formulary. 